\author{
우포늪 저서성 대형무척추동물 군집의 \\ 장기생태모니터링을 위한 기반조사 \\ 이동준·윤춘식·이준철·성성훈·박다라·정선우 \\ 창원대학교 생물학과 \\ (2009년 7월 25일 접수; 2009년 8월 23일 수정; 2009년 9월 28일 채택)
}

\title{
Fundamental Investigation for Long-term Ecological Monitoring on Community of Benthic Macroinvertebrates in Wetland Woopo
}

\author{
Dong-Jun Lee, Chun-Sik Yoon, Jun-Cheol Lee, Sung-Hoon Sung, \\ Da-Ra Park and Seon-Woo Cheong \\ Department of Biology, Changwon National University, Kyungnam 641-773, Korea
}

(Manuscript received 25 July, 2009; revised 23 August, 2009; accepted 28 September, 2009)

\begin{abstract}
The study on community structure of benthic macroinvertebrates from wetland Woopo was conducted for the long-term ecological monitoring. The wetland Woopo is located in Changnyeong-Gun, Gyeongsangnam - Do of Korea. In 2006, we investigated the seasonal variation of benthic macroinvertebrates with quantitative and qualitative collecting methods. The collection was performed monthly at four surveying region, Woopo, Sajipo, Mokpo and Topyong stream. In this study, 6 classes, 16 orders, 48 families, 95 species were identified on group of benthic macroinvertebrates. The species diversity index and the species richness index were the highest in Topyung region and it was 3.222 and 10.216 respectively. The two species, Cercion calamorum and Cloeon dipterum were quantitatively collected for 9 months. The changes of body lengths of 50 individuals were recorded and the advanced growth on the two species was expected from present study.
\end{abstract}

Key Words : Benthic macroinvertebrates, Wetland Woopo, Long-term ecological monitoring

\section{1. 서 론}

생태계 연구에서 산림의 천이나 많은 종류의 동 물 개체군의 변동주기와 같은 것들은 2,3 년의 단기 적 생태계 연구에 의해서는 파악될 수 없으므로 장 기모니터링연구를 함으로써 점진적인 생태계 변화 의 과정과 기작을 파악할 수 있다. 이는 또한 예기치

Corresponding Author: Seon-Woo Cheong, Department of Biology, Changwon National University, Kyungnam 641-773, Korea

Phone: +82-55-213-3454

E-mail: swcheong@changwon.ac.kr
못한 생태계의 변화, 즉 산불의 발생이나 각종 사고 에 의한 생태계 파괴와 그 영향 등을 파악할 수 있 으며, 생태계 변화의 미묘한 과정 및 기작을 파악하 며 생태계 평가의 오류를 줄일 수 있다. 대부분의 생태계에서 단기간 연구에서 드러나는 변화의 양상 들은 장기적으로 볼 때 과대평가되는 경우가 많으 며 따라서 생태계의 합리적 파악에 장애가 될 수 있 다. 또한 생물군집과 같이 복잡한 구조를 갖는 생태 계 내에서 생물적 및 비생물적 요인들 사이의 생태 학적 상호관계의 파악은 단기적 연구를 통해서 이 
루어질 수 없으므로 복잡한 생태계 변화의 양상을 파악할 수 있다는 점에서 그 가치와 필요성을 인정 받고 있다 ${ }^{1)}$. 국외에서는 다양한 무척추동물에 대하 여 장기모니터링연구가 이루어져 왔는데 예를 들 면, 미국 뉴저지에서는 수십 년간 매달 모기개체군 을 조사하여 기후변화와 모기개체군의 변화를 연관 시켜 분석한 연구가 있으며 ${ }^{2)}$, 영국에서는 지구온난 화에 의한 나비의 출현양상의 변화에 대해 장기간 연구한 사례가 있다. 그 연구에서는 나비의 출현일 과 기온과의 관계를 20 년 이상 추적하여 비교한 결 과 나비들이 과거에 비해 더욱 북쪽에서 대부분 나 타나는 것으로 보고되었다. 이는 지구의 급격한 온 난화에 대한 나비의 적응력을 보여주는 한 예라는 결론을 내린바 있다. 그러나 국내에서는 본격적인 장기모니터링연구는 이루어지지 않았으며 진행 중 인 연구들도 모두 초입단계에 있는 실정이다.

저서성 대형무척추동물은 담수생태계의 생물 중 에서 가장 높은 종다양성과 개체수 현존량을 나타 내고 있으며, 담수생태계의 저차 소비자로서 영양 단계의 중추적 위치에 있다 ${ }^{3,4)}$. 특히 이들은 정수와 유수생태계의 다양한 서식처에 적응하고 있을 뿐만 아니라 생활사가 짧으며 정량채집이 용이하기 때문 에 생태학적 연구 재료로 많이 이용되고 있다 ${ }^{5)}$. 뿐 만 아니라 많은 종류의 저서무척추동물이 환경 변 화에 민감하게 반응하여 분포를 달리 하므로 수질 과 환경변화의 지표생물로서 많이 이용된다. 따라 서 어느 담수생태계의 특성을 파악하기 위해서는 그 지역의 저서무척추동물에 대한 개체군의 출현 양상과 군집의 특성을 분석하는 것이 필요하다.

경남 창녕군 이방면, 대합면, 유어면, 대지면 등 4 개면 일대에 걸쳐 있는 우포늪은 낙동강 지류인 토 평천의 중, 하류 유역에 걸쳐 형성되어 있으며 국내 에서는 거의 유일하게 남아있는 대규모의 자연습지 로서 우포늪, 목포늪, 사지포늪, 쪽지벌 등의 4개의 늪으로 이루어져 있으며 수면적이 $230 \mathrm{ha}$ 에 달하는 국내 최대의 늪지로 그 생태적 가치와 보전의 필요 성이 인정되어 환경부고시 1997-66호에 의해 1997 년 7월 26일 생태계보전지역 중 생태계특별보호구 역으로 지정되었다. 우포늪은 국제적으로도 1998년 3월 2일 람사르협약 보존습지로 지정되었고, 1999 년 8월 9일 습지보호지역으로 지정되어 있다. 그러
나 이러한 생태적 중요성에도 불구하고 우포습지 일대에서 이루어진 저서성 대형무척추동물에 대한 연구에서 서식종의 현황조사는 간헐적으로 이루어 져 왔으나 장기적 모니터링은 행해진 바 없었다 ${ }^{6 \sim 8)}$.

본 연구의 목표는 우포습지일대에서 우포, 목포, 사지포, 토평천 지역의 저서성 대형무척추동물의 기본현황을 파악하고 종다양성과 계절적 군집의 특 성을 규명하여 장기적인 변화양상과 그 변화에 따 른 영향을 예측함에 있어 중요한 기초적 자료로 활 용될 수 있는 장기모니터링의 기반을 조성하는 것 이다. 이러한 연구를 위하여 저자들은 2005년에 이 미 우포늪의 저서성 대형 무척추동물의 계절별 조 사를 하여 그 분포현황을 조사한 바 있다. 본 조사에 서는 이들 개체군의 월별 변화를 파악하기 위하여 조사지점별, 월별 조사를 하였으며, 추가적으로 중 점모니터링의 대상종을 선정하여 개체군의 출현양 상과 길이측정을 함으로써 성숙정도의 변화를 지속 적으로 조사하여 장기모니터링조사의 기반을 구성 하는데 초점을 맞추었다.

\section{2. 재료 및 방법}

\section{1. 조사지점 및 개황}

우포늪 일대의 4 개 조사지역을 대상으로 조사하 였으며 (Fig. 1.) 조사지역의 행정구역은 다음과 같다.

-우포(A): 경상남도 창녕군 유어면 세진리

-목포(B): 경상남도 창녕군 이방면 옥천리

-사지포 $(\mathrm{C})$ : 경상남도 창녕군 대합면 주매리

-토평천유입부(D): 경상남도 창녕군 대합면 주 매리

우포의 조사지점은 우포의 서쪽 도로와 인접한 지역이며 접근이 비교적 쉬운 곳으로 하였다. 동계 조사 시에는 철새들로 인하여 새들의 분변, 깃털 등 으로 호수의 바닥이 오염되어 있고 논우렁이의 껍 질이 널려있으며 수량이 많이 줄어들어 있었다. 정 수구역이므로 물의 흐름은 거의 없고 통행차량 및 관광객의 왕래가 주된 교란요인이며 늪지 내 수질 변화요인은 철새들의 분변과 둔터마을에서 유입되 는 오염물질들로 보였다. 하계 조사 시에는 수면의 거의 대부분을 수생식물들이 덮고 있었으며 갈수기 와 수량차가 확연히 드러나는 지역이다. 하계 조사 를 제외하고는 저수구역 내의 수초 등은 매우 빈약 


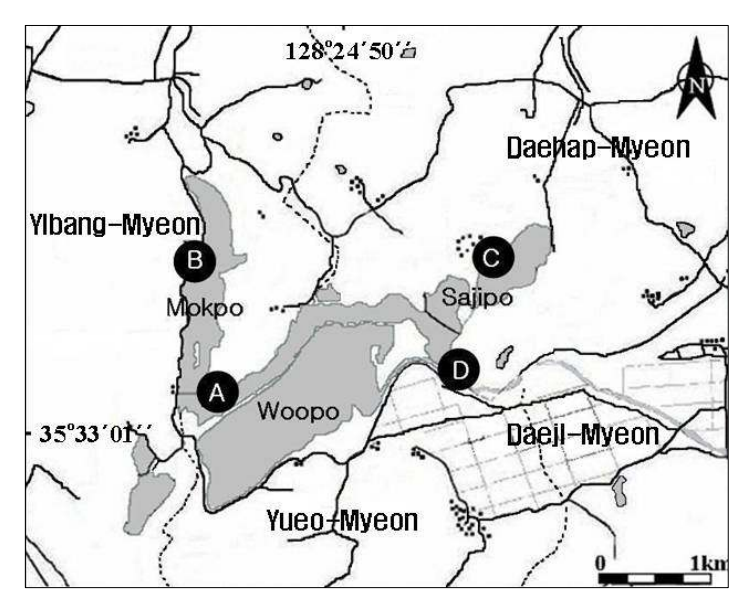

Fig. 1. A map showing surveyed sites of wetland Woopo. (A) Woopo site (B) Mokpo site (C) Sajipo site (D) Topyung site

하였고 바닥은 대부분 점토로 이루어져 있었다.

목포의 조사지점은 목포의 북쪽일대이며 목포의 서편으로 비포장도로가 있어 접근이 유리하다. 조 사지점 서쪽으로 과수원과 마늘 밭이 있어 농약사 용이 예상된다. 바닥은 점토와 사질토양으로 이루 어져 있었고, 부패로 인한 악취가 극심하였다. 도로 서편의 산지에서 계류가 유입되고 있으며 마을은 도로에서 상당히 멀리 떨어져 있었다. 그러나 정치 망이 목포 내에 설치되어 있는 점 등으로 보아 어로 를 위한 인간의 간섭은 심한 것으로 보였다. 다른 지역과 마찬가지로 하절기에는 수면의 대부분이 수 생식물로 덮이며 수변식물은 풍부하여 어류나 저서 성 대형무척추동물의 서식에는 유리한 환경으로 사 료된다.

사지포의 조사지점은 사지포의 동쪽지역이며 주 변은 농지로서 묵혀 둔 밭이 많다. 도로에서 멀어 접근에 비교적 불리하였으며 바닥은 모두 점토와 사질 토양이었다. 이 지역은 접근이 불리하여 감시 가 소홀한 지역으로서 낚시꾼들의 출입이 자주 목 격되는 지역이다. 저수구역으로 접근하는 도중 호 안의 형태가 복잡하여 다양한 미소서식처를 갖춘 곳으로 생각되며 저서성 대형무척추동물의 서식에 유리한 곳으로 판단된다.

토평천유입부의 조사지점은 토평천이 우포의 동 쪽으로 유입되는 곳이며 교량신설사업으로 토평천 교란이 심한 곳도 있어 조사는 공사 지점과는 상당
히 이격된 곳에서 행하였다. 동계 조사와 춘계 조사 시는 하천의 물이 줄어 바닥이 드러난 곳이 많았으 며 하계 조사 시와 추계 조사 시에는 유속이 빨랐으 며 일부 정수 지역도 있어 다양한 서식처를 제공하 고 있었다. 하상은 주로 모래와 점토로 구성되어 있 으며 자갈과 호박돌도 혼재하였다.

\section{2. 조사시기}

본 조사는 정량조사와 정성조사를 병행하였으며 각 지점별 저서성 대형무척추동물의 서식현황과 변 화를 모니터링하기 위하여 2006년 2월부터 10월까 지 매월 20 일에 조사하되 강수로 인해 습지내의 교 란이 있을 경우 2 3일 경과 후 조사하였다.

\section{3. 조사방법}

\subsection{1. 정량조사}

유수지역의 정량채집은 Surber-net을 이용한 방법 이 일반적이나 본 조사지점은 정수역이 대부분으로 제 2 차 전국자연환경 조사 지침의 정수지역의 정량 채집법에 따라 폭이 $50 \mathrm{~cm}$ 인 D frame-net을 사용하 여 조사지점별로 수초가 풍부한 연안대의 서식처를 대표하는 2 개 지점을 선정하여 $1 \mathrm{~m}$ 거리의 동일한 지점의 바닥을 2 회 홇어서 조사하였다(총 $\left.2 \mathrm{~m}^{2}\right)^{9)}$.

\subsection{2. 정성조사}

폭이 $30 \mathrm{~cm}$ 인 hand net과 원형뜰채 등을 이용하여 수초가 있는 곳, 가장자리, 낙엽 쌓인 곳, 모래 등 다양한 미소서식처에서 한 지점 당 30 분 이상 보충 채집하였다. 그 외의 채집 및 서식처의 환경조사 방 법은 일반적인 조사 방법을 따랐다 ${ }^{10 ~ 13)}$.

\subsection{3. 중점 모니터링대상종의 채집}

기후의 변화가 저서성 대형무추동물에 미치는 영 향을 모니터링하기 위해 등검은실잠자리(Cercion calamorum)와 외날개꼬마하루살이(Cloeon dipterum) 를 정성조사 방법으로 매월 50 개체를 채집하여 꼬 리아가미의 길이를 제외한 체장을 재어 그 값들의 변화를 기록하였다. 이 들은 각각 수중생태계의 먹 이사슬 관계에서 2 3차 소비자와 1차 소비자로서 매우 중요한 위치를 점하고 있으며, 유충의 성장이 기온의 변화에 민감하고 매월 모니터링에 필요한 충분한 개체수의 확보가 용이하기 때문에 모니터링 대상종으로 선정하였다.

현장에서 채집된 표본은 $500 \mathrm{ml}$ 유리병에 넣고 
고정액(Kahle's Solution; 에틸 알콜 $28 \%$, 포르말린 $11 \%$, 초산 $2 \%$, 증류수 $59 \%$ )으로 고정하였다. 표본 은 하루 정도 고정한 후 $80 \%$ 에틸 알콜 용액으로 옮겨 보관하였다.

\section{4. 표본의 동정 및 정리}

채집된 저서성 대형무척추동물은 관련자료를 참 고하여 실체현미경하에서 동정 분류하였고, 수서곤 충류 중 깔다구과(Chironomidae)의 경우 체장, 체색, mouth part의 형태, abdominal tubles의 유무, 강모의 형태 등의 특징을 고려하여 분류하였다 ${ }^{14 ~ 24)}$. 분류 된 저서성 대형무척추동물은 한국곤충명집과 한국 동물명집에 따라 정리하여 목록을 작성하였으며 이 들 자료를 기초로 출현종, 분포상황, 주요종 등을 파 악하였다 ${ }^{25,26)}$.

\section{5. 군집분석}

정량채집으로 조사된 저서성 대형무척추동물들 을 대상으로 종다양도지수, 종풍부도지수, 우점도 지수를 산출하였다 ${ }^{27,28)}$.

\section{3. 결과 및 고찰}

\section{1. 서식현황}

\subsection{1. 저서성 대형무척추동물상}

본 연구에서는 우포늪에서 6강 18목 48과 95종의 다양한 저서성 대형무척추동물이 조사되었는데 조 사지점별 출현종은 우포에서 5강 13목 31과 55종, 목포에서 5 강 13 목 31 과 60 종, 사지포에서 5강 13 목 33 과 51종, 토평천에서 6 강 15 목 36 과 74 종이 조사 되었다. 이 중에서 종 수준까지의 동정이 되지 않아 $\mathrm{sp}$.로 기록된 종들을 제외하고도 29종은 현재까지 우포늪일대에서 조사되어 기록되지 않았던 종으로 금번 조사에서 처음으로 기록되었다. 새로 조사된 종을 살펴보면 수서곤충류에는 하루살이목에 동양 하루살이(Ephemera orientalis), 잠자리목에 자실잠 자리Copera annulata) 등 7종, 노린재목에 메추리장 구애비(Nepa hoffmanni), 애실소금쟁이(Hydrometra procera) 등 5종, 딱정벌레목에 알물 땡땡이(Amphiops mater)와 둥글넓적물땡땡이(Enochrus (Lumetus) subsignatus) 등 7종, 파리목에 줄동애등에 $\mathrm{KUa}($ Stratiomys $\mathrm{KUa}$ ) 등 3종, 십각목에 새뱅이(Cardina denticulata denticulata)와 징거미새우(Mactobrachium nipponense)
등 3종, 기안목에 애기물달팽이(Austropeplea ollula) 와 또아리물달팽이(Gyraulus chinensis) 등 2종, 턱거 머리목에서 1 종이 우포의 문헌기록에는 없던 종이 었다(Table 1).

\subsection{2. 출현종의 구성비}

채집된 저서성 대형무척추동물은 곤충강에서 80 종으로 전체의 $80 \%$ 를 차지하였으며 갑각강은 4 종 으로 전체의 $4.21 \%$, 복족강은 9 종으로 $9.47 \%$, 이매 패강은 2 종으로 $2.11 \%$, 빈모강에서 1 종으로 $1.05 \%$, 거머리강에서 3 종으로 $3.16 \%$ 로 각각 나타났다. 저 서성대형무척추동물 중 가장 높은 비율을 차지하는 수서곤충은 잠자리목이 23종으로 가장 많았으며 그 다음으로는 노린재목에서 18종, 딱정벌레목에서 17 종, 파리목에서 13 종, 하루살이목과 날도래목이 각 각 2종, 나비목 1 종 등의 순으로 조사되었다. 갑각강 에서는 십각목이 3 종으로 가장 많았으며 등각목 1 종이 조사되었다. 복족강은 기안목이 6종, 중복족목 이 3 종이 조사되었고, 이매패강에서는 석패목과 백 합목에서 각각 1 종이 조사되었다. 거머리강에서는 턱거머리목에서 2종, 부리거머리목에서 1종이 조사 되었고, 빈모강에서는 물지렁이목 1 종이 조사되었다.

\section{2. 월별모니터링}

3.2.1. 조사지점별 월별 출현종 및 개체수의 변화 우포지점에서 채집된 저서성 대형무척추동물은 2 월에 8 종 36 개체였으며 3 월에는 10 종 31 개체, 4 월 에는 21 종 134 개체, 5 월에는 30 종 194 개체, 6 월에는 15 종 122 개체, 7 월에는 17 종 170 개체, 8 월에는 15 종 87 개체, 9월에는 28 종 110 개체, 10 월에는 30 종 151 개체로 나타났다. 춘계에 해당하는 4 월, 5 월과 추계 에 해당하는 9 월, 10 월에 종수와 개체수가 많은 것 으로 조사되었다. 목포지점에서 채집된 저서성 대 형무척추동물은 2월에 13종 67개체였으며 3월에 13 종 76 개체, 4월에 20종 161 개체, 5월에 25종 251 개 체, 6월에 20종 117 개체, 7 월에 14종 37 개체, 8 월에 17 종 54 개체, 9 월에 8 종 28 개체, 10 월에 16 종 85 개체 로 나타났다. 5월에 가장 많은 종수와 개체수가 조 사되었으며 9월에 가장 적은 것으로 조사되었다. 사 지포지점에서 채집된 저서성 대형무척추동물은 2 월에 13 종 41 개체였으며 3월에 13종 41개체, 4월에 21 종 220 개체, 5월에 15 종 276개체, 6월에 12종 135 
Table 1. Taxonomic list of benthic macroinvertebrates to the site of wetland Woopo

\begin{tabular}{|c|c|c|c|c|c|}
\hline Taxa & $\begin{array}{l}\text { Collected } \\
\text { sites }\end{array}$ & $\begin{array}{c}\text { Reference } \\
\text { survey } \\
\text { (year) }\end{array}$ & Taxa & $\begin{array}{l}\text { Collected } \\
\text { sites }\end{array}$ & $\begin{array}{l}\text { Reference } \\
\text { survey } \\
\text { (year) }\end{array}$ \\
\hline $\begin{array}{l}\text { Phylum Arthropoda } \\
\text { Class Insecta }\end{array}$ & & & $\begin{array}{l}\text { Sigara subatrita } \\
\text { Family Pleidae }\end{array}$ & 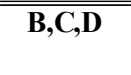 & 87,04 \\
\hline Order Ephemeroptera & & & Plea (Paraplea) indistinguenda & $\mathbf{A}, \mathbf{B}, \mathbf{C}, \mathbf{D}$ & 04 \\
\hline Family Baetidae & & & Family Naucoridae & & \\
\hline $\begin{array}{l}\text { Cloeon dipterum } \\
\text { Family Ephemeridae }\end{array}$ & $\mathbf{A , B}, \mathbf{C}, \mathbf{D}$ & 87,04 & $\begin{array}{l}\text { Ilyocoris exclamationis } \\
\text { Family Hydrometridae }\end{array}$ & $\mathbf{A}, \mathbf{C}$ & 87,04 \\
\hline $\begin{array}{c}\text { Ephemera orientalis } \\
\text { Order Odonata }\end{array}$ & D & & $\begin{array}{l}\text { Hydrometra procera } \\
\text { Family Voliidae }\end{array}$ & $\mathbf{A}, \mathbf{B}, \mathbf{C}$ & \\
\hline Family Coenagrionidae & & & Microvelia reticula & $\mathbf{A}, \mathbf{B}, \mathbf{C}, \mathbf{D}$ & \\
\hline Cercion calamorum calamorum & A,B,C,D & 87,04 & Pseudovelia tibialis tibialis & C,D & 04 \\
\hline Cercion hieroglyphicum & $\mathbf{A}, \mathbf{B}, \mathbf{C}, \mathbf{D}$ & 04 & Family Gerridae & & \\
\hline Ischnura asiatica & A,B,C,D & 87,04 & Aquarius paludum & $\mathbf{A , B}, \mathbf{C}, \mathbf{D}$ & 87 \\
\hline Family Platycnemididae & & & Gerris (Gerris) latiabdominis & $\mathbf{A}, \mathbf{B}, \mathbf{C}, \mathbf{D}$ & 04 \\
\hline Platycnemis phillopoda & $\mathbf{A , B}, \mathbf{C}, \mathbf{D}$ & 04 & Gerris (Gerriselloides) nepalensis & A,B,C,D & \\
\hline $\begin{array}{l}\text { Copera annulata } \\
\text { Family Lestidae }\end{array}$ & $\mathbf{A}, \mathbf{B}, \mathbf{D}$ & & $\begin{array}{l}\text { Metrocoris histrio } \\
\text { Order Coleoptera }\end{array}$ & $\mathbf{A}, \mathbf{C}, \mathbf{D}$ & \\
\hline Lestes sponsa & $\mathbf{B}, \mathbf{D}$ & 87 & Family Haliplidae & & \\
\hline $\begin{array}{l}\text { Family Calopterygidae } \\
\text { Calopteryx atrata }\end{array}$ & A,B,C,D & 04 & $\begin{array}{l}\text { Peltodytes sinensis } \\
\text { Family Dytiscidae }\end{array}$ & A,B,C,D & 04 \\
\hline $\begin{array}{l}\text { Calopteryx japonica } \\
\text { Family Gomphidae }\end{array}$ & A,B,C,D & & $\begin{array}{l}\text { Laccophilus difficilis } \\
\text { Platambus firmbriatus fimbriatus }\end{array}$ & $\begin{array}{c}\mathbf{A}, \mathbf{B}, \mathbf{C}, \mathbf{D} \\
\mathbf{A}, \mathbf{B}, \mathbf{D}\end{array}$ & 87 \\
\hline Trigomphus melampus & D & 04 & Guignotus japonicus & & 04 \\
\hline Stylurus annulatus & D & & Laccophilus sp. & $\mathbf{A}, \mathbf{B}, \mathbf{C}$ & \\
\hline $\begin{array}{l}\text { Family Aeshnidae } \\
\text { Aeshna nigorflava }\end{array}$ & B,C,D & & $\begin{array}{l}\text { Agabus sp. } \\
\text { Family Noteridae }\end{array}$ & A,B,C,D & \\
\hline $\begin{array}{l}\text { Aeshna juncea } \\
\text { Anax parthenope ju }\end{array}$ & $\begin{array}{c}\mathbf{B} \\
\mathbf{A}, \mathbf{B}, \mathbf{C}, \mathbf{D}\end{array}$ & $\begin{array}{c}04 \\
87,04\end{array}$ & $\begin{array}{l}\text { Noterus japonicus } \\
\text { Family Gyrinidae }\end{array}$ & $\mathbf{A , B}, \mathbf{C}, \mathbf{D}$ & 04 \\
\hline $\begin{array}{l}\text { Anax parthenope Juluus } \\
\text { Family Corduliidae } \\
\text { Macromia amphigena fraenata }\end{array}$ & A,B,C,Ш & 87,04 & $\begin{array}{l}\text { Gyrinus (Gyrinus) japonicus francki } \\
\text { Family Hydrophilidae }\end{array}$ & A,D & 87 \\
\hline $\begin{array}{l}\text { Epophthalmia elegans yagasakii } \\
\text { Family Libellulidae }\end{array}$ & $\mathbf{A}, \mathbf{B}, \mathbf{C}, \mathbf{D}$ & 87 & $\begin{array}{l}\text { Amphiops mater } \\
\text { Enochrus (Lumetus) subsignatus }\end{array}$ & $\begin{array}{l}\text { A,B,C,D } \\
\text { A,B,C,D }\end{array}$ & \\
\hline Crocothrmis sercilia servilia & $\mathbf{A}, \mathbf{B}, \mathbf{D}$ & 04 & Enochrus (Lumetus) esuriens & $\mathbf{A}, \mathbf{B}, \mathbf{C}, \mathbf{D}$ & \\
\hline Deielia phaon & $\mathbf{A , B}, \mathbf{C}, \mathbf{D}$ & 04 & Enochrus (Holcophilydrus) simulans & $\mathbf{A , B}, \mathbf{C}, \mathbf{D}$ & \\
\hline Orthetrum albistylum speciosum & $\mathbf{A , B}, \mathbf{C}, \mathbf{D}$ & 87,04 & Enochrus (Holcophilydrus) umbratus & B,C,D & \\
\hline Orthetrum lineostigma & A,B,D & 04 & Laccobius (Laccobius) bedeli & $\mathbf{A , B}, \mathbf{D}$ & 04 \\
\hline Orthetrum triangulare melania & B,D & 87 & Helochares (Hydrobaticus) striatus & $\mathbf{A}, \mathbf{B}, \mathbf{C}, \mathbf{D}$ & 04 \\
\hline Sympetrum striolatum imitoides & D & & Sternolophus (Sternolophus) rufipes & A,B,C,D & 87,04 \\
\hline Sympetrum pedemontanum elatum & B,D & 87 & Family Chrysomelidae & & \\
\hline $\begin{array}{l}\text { Sympetrum depressiusculum } \\
\text { Order Hemiptera } \\
\text { Family Nepidae }\end{array}$ & B,D & & $\begin{array}{c}\text { Galerucella nipponensis } \\
\text { Order Diptera } \\
\text { Family Psychodidae }\end{array}$ & C,D & \\
\hline Laccotrephes japonensis & A,B,C,D & 87 & Psychoda Kua & B & \\
\hline Nepa hoffmanni & D & & Family Culicidae & & \\
\hline Ranatra chimemsis & A,B,C,D & 87,04 & Culicidae sp. & $\mathbf{A}, \mathbf{B}, \mathbf{C}$ & \\
\hline Ranatra unicolor & $\mathbf{A}, \mathbf{C}$ & 04 & Family Syrphidae & & \\
\hline Family Belostomatidae & & & Eristalis $\mathrm{KUa}$ & $\mathbf{A}, \mathbf{D}$ & \\
\hline Diplonychus japonicus & B,D & 87,04 & Family Ceratopogonidae & & \\
\hline $\begin{array}{l}\text { Diplonychus esakii } \\
\text { Family Corixidae }\end{array}$ & $\mathbf{A}, \mathbf{B}, \mathbf{C}, \mathbf{D}$ & 87 & $\begin{array}{l}\text { Culicoides sp. } \\
\text { Family Simuliidae }\end{array}$ & $\mathbf{C}$ & \\
\hline Hesperocorixa kolthoffi & B,C & 87,04 & Simulium sp. & D & \\
\hline Micronecta(Basilionecta) sedula & $\mathbf{A}, \mathbf{B}, \mathbf{C}, \mathbf{D}$ & 87,04 & Family Chironomidae & & \\
\hline
\end{tabular}


Table 1. Continued

\begin{tabular}{|c|c|c|c|c|c|}
\hline Taxa & $\begin{array}{l}\text { Collected } \\
\text { sites }\end{array}$ & $\begin{array}{c}\text { Reference } \\
\text { survey } \\
\text { (year) }\end{array}$ & Taxa & $\begin{array}{l}\text { Collected } \\
\text { sites }\end{array}$ & $\begin{array}{l}\text { Reference } \\
\text { survey } \\
\text { (year) }\end{array}$ \\
\hline Chironomus sp.1 & $\mathbf{A , B}, \mathbf{C}, \mathbf{D}$ & & Order Veneroida & & \\
\hline Chironomus sp. 2 & $\mathbf{A , B}, \mathbf{C}, \mathbf{D}$ & & Family Corbiculidae & & \\
\hline Chironomus sp. 3 & $\mathbf{A , B}, \mathbf{C}, \mathbf{D}$ & & Corbicula fluminea & C,D & 04 \\
\hline Chironomus sp.4 & $\mathbf{A , B}, \mathbf{C}, \mathbf{D}$ & & Phylum Annelida & & \\
\hline Chironomus sp. 5 & $\mathbf{A , B}, \mathbf{C}, \mathbf{D}$ & & Class Oligochaeta & & \\
\hline Chironomus sp.6 & $\mathbf{A}, \mathbf{B}, \mathbf{C}, \mathbf{D}$ & & Order Archioligochaeta & & \\
\hline Chironomus sp.7 & B,C,D & & Family unknown & & \\
\hline $\begin{array}{l}\text { Chironomus sp. } 8 \\
\text { Family Stratiomyidae }\end{array}$ & C,D & & $\begin{array}{l}\text { Archioligochaeta sp. } \\
\text { Class Hirudinea }\end{array}$ & A,B,C,D & \\
\hline Stratiomys KUa & $\mathbf{A}, \mathbf{B}, \mathbf{C}$ & & Order Arhynchobdellidae & & \\
\hline Order Trichoptera & & & Family Hirudinidae & & \\
\hline Family Ecnomiidae & & & Whitmania edentula & A,B,D & \\
\hline $\begin{array}{l}\text { Ecnomus tenellus } \\
\text { Family Phryganeidae }\end{array}$ & A,D & 04 & $\begin{array}{l}\text { Family Erpobdellidae } \\
\text { Eropobdella lineata }\end{array}$ & $\mathbf{A}, \mathbf{B}, \mathbf{C}$ & 04 \\
\hline $\begin{array}{l}\text { Agrypnia pagetana } \\
\text { Order Lepidoptera }\end{array}$ & $\mathbf{C}$ & 87 & $\begin{array}{l}\text { Order Rhynchobdellida } \\
\text { Family Glossiphoniidae }\end{array}$ & & \\
\hline Family Pyralidae & & & Alboglossiphonia lata & $\mathbf{A}, \mathbf{B}, \mathbf{C}, \mathbf{D}$ & 04 \\
\hline $\begin{array}{c}\text { Pyralidae sp. } \\
\text { Class Crustacea } \\
\text { Order Decapoda } \\
\text { Family Atyidae }\end{array}$ & $\mathbf{A}, \mathbf{B}, \mathbf{C}$ & & & & \\
\hline Cardina denticulata denticulata & $\mathbf{A}, \mathbf{B}, \mathbf{C}, \mathbf{D}$ & & & & \\
\hline $\begin{array}{l}\text { Caridina denticulata sinensis } \\
\text { Family Palaemonidae }\end{array}$ & A,B,C,D & & & & \\
\hline $\begin{array}{c}\text { Mactobrachium nipponense } \\
\text { Order Isopoda }\end{array}$ & B,C,D & & & & \\
\hline Family Asellodae & & & & & \\
\hline $\begin{array}{c}\text { Asellus sp. } \\
\text { Phylum Mollusca } \\
\text { Class Gastropoda } \\
\text { Order Mesogastropoda } \\
\text { Family viviparidae }\end{array}$ & A,B,C,D & & & & \\
\hline Cipangopaludina japonica & $\mathbf{A , B}, \mathbf{C}, \mathbf{D}$ & 04 & & & \\
\hline $\begin{array}{l}\text { Cipangopaludina chinensis malleata } \\
\text { Family Bithyniidae }\end{array}$ & A,B,C,D & 04 & & & \\
\hline $\begin{array}{l}\text { Gabbia misella } \\
\text { Order Basommatophora } \\
\text { Family Lymnaeidae }\end{array}$ & A,B,C,D & 04 & & & \\
\hline Austropeplea ollula & A,B,C,D & & & & \\
\hline $\begin{array}{l}\text { Radix auricularia } \\
\text { Family Physidae }\end{array}$ & A,B,C,D & 04 & & & \\
\hline $\begin{array}{l}\text { Physilla acuta Draparnud } \\
\text { Family planorbidae }\end{array}$ & $\mathbf{A , B}, \mathbf{C}, \mathbf{D}$ & 04 & & & \\
\hline Gyraulus chinensis & $\mathbf{A}, \mathbf{B}, \mathbf{C}, \mathbf{D}$ & & & & \\
\hline Hippeutis cantori & A,B,C,D & 04 & & & \\
\hline $\begin{array}{c}\text { Polypylis hemisphaerula } \\
\text { Class Bivalvia } \\
\text { Order Unionidae } \\
\text { Family Unionidae }\end{array}$ & A,B,C,D & 04 & & & \\
\hline Anodonta (Anemia) arcaefomis & & 04 & & & \\
\hline Unio douglasiae & $\mathbf{A}, \mathbf{B}, \mathbf{C}, \mathbf{D}$ & 04 & & & \\
\hline
\end{tabular}

(A) Woopo, (B) Mokpo, (C) Sajipo, (D)Topyung 
개체, 7월에 13 종 42 개체, 8 월에 12 종 48 개체, 9월에 26 종 140 개체, 10 월에 12 종 54 개체로 나타났다. 9월 에 가장 많은 종이 채집되었고 개체수는 5 월이 가장 많았으며 2월과 3 월에 가장 적은 종수와 개체수가 조사되었다. 토평천지점에서 채집된 저서성 대형무 척추동물은 2월에 8 종 30 개체였으며 3 월에 50 종 255 개체, 4월에 25 종 267 개체, 5월에 29종 228개체, 6 월에 22종 75 개체, 7 월에 9종 42개체, 8 월에 15 종 91 개체, 9월에 19종 82개체, 10월에 25종 199개체로 나타났다. 3 월에 가장 많은 종이 채집되었고 개체수 는 4월이 가장 많았으며 2월에 가장 적은 종수와 개 체수가 조사되었다(Fig. 2).

출현종수와 개체수는 춘계에 해당하는 3 월부터 5 월까지 많은 종수와 개체수를 나타내었으며 우포지 점을 제외하고는 모두 6월과 7월에 종수와 개체수 가 현저하게 줄었는데 이는 6월부터 시작된 강우로 인한 수환경의 변화가 주된 원인으로 생각된다. 이 와 같이 우포지역에서 7월에 출현종 및 개체수가 증 가한 것은 토평천과 목포늪에 서식하던 무척추동물 일부가 중 증가한 수량과 빨라진 유속에 떠밀려 우 포지역으로 내려와 그대로 정착한 것이기 때문으로 생각된다.

\subsection{2. 조사지점별 군집구조의 변화}

우포지역의 종다양도는 2월에 1.789로 비교적 낮 았으나 5월까지 꾸준히 상승하여 5월에는 2.707로 높아졌다가 6월에는 1.955로 다시 낮아졌고 7월에 는 1.870 으로 나타났다. 그러나 9월에는 종다양도가 다시 높아져 2.958로 가장 높은 것으로 조사되었다. 종풍부도는 2월에 1.985 로 가장 낮았으며 10 월에 5.780 으로 가장 높게 나타났다. 우점도는 2월에 0.613 으로 가장 높았으며 9월에 0.290로 가장 낮게 나타났다. 목포지역의 종다양도는 2월에 2.067로 다 른 지역에 비하여 높은 것으로 나타났으며 우포지 역과 마찬가지로 5월까지 상승하여 5월에 2.638로 가장 높게 나타났으며 6월과 7월에 낮아졌다가 8월 에 다시 2.526으로 상승하였다가 9월에 1.837로 연 중 최저치를 나타내었으며 10 월에 2.114로 다시 높 게 나타났다. 종풍부도는 9월에 2.101로 가장 낮았 으며 5월에 4.344로 가장 높은 것으로 나타났다. 우점 도는 5월에 0.327 로 가장 낮았으며 10 월에 0.552 로 가 장 높았다. 사지포지역의 종다양도는 9월에 2.651로

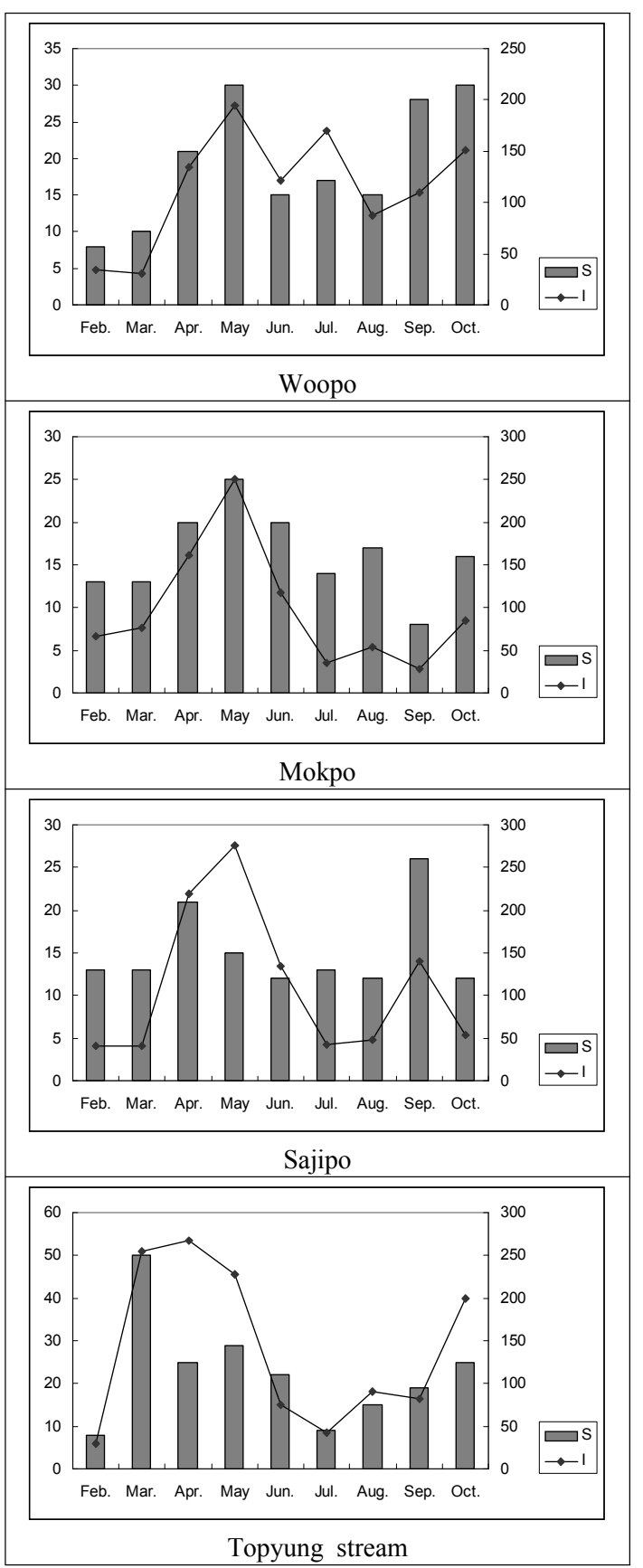

Fig. 2. Changes of a monthly collected species and individuals in each surveyed sites.

(S) Species, (I) Individuals

가장 높게 나타났으며 5월에 1.472로 가장 낮게 나 타났다. 종풍부도는 9월에 5.059로 가장 높은 것으 
로 나타났고 6월에 2.242로 가장 낮았으며 우점도는 9월에 0.392로 가장 낮았고 5월에 0.757로 가장 높았 다. 토평천지역의 종다양도는 2월에 1.507 로 가장 낮았으며 3월에 3.115로 가장 높게 나타났다. 종풍 부도는 2월에 2.058로 가장 낮았으며 3월에 8.843으 로 가장 높게 나타났다. 우점도는 6월에 0.320으로 가장 낮았으며 2월에 0.667로 가장 높았다(Table 2).

6월에 강우로 담수생태계의 자연적인 교란이 발 생하여 종다양도와 종풍부도가 낮아져 단순한 군집 구조를 보였으나 이후 종다양도와 종풍부도는 다시 높아져 안정적인 군집구조로 회복되었다. 일반적으 로 인위적인 교란에 의해 영향을 받은 생태계가 다 시 회복하기 위해서는 오랜 기간이 걸리는데 비해 우포의 저서생물의 군집은 빠른 회복속도를 보였는 데 이는 여름철의 집중호우와 같은 주기적으로 발 생하는 자연적인 교란의 경우 오랜 기간을 이와 같 은 서식환경에서 생존해왔던 종들이 이미 적응력을 가지고 있었기 때문인 것으로 사료된다.

\subsection{3. 중점 모니터링대상종의 조사결과}

본 연구에서는 등검은실잠자리(Cercion calamorum calamorum)와 외날개꼬마하루살이(Cloeon dipterum) 두 종을 중점 모니터링대상종으로 설정하였 는데 이 두 종은 유영성이 강하지 않고 수초 등 기 질에 부착생활을 하여 홍수와 같은 물리적인 교란 과 온도변화 등의 환경변화에 민감하면서도 모니터
링에 필요한 최소한의 개체수를 안정적으로 확보하 는데 용이하기 때문에 선택하였다.

\subsubsection{1. 등검은실잠자리의 체장의 변화}

2월에는 $5 \mathrm{~mm}$ 부터 $13 \mathrm{~mm}$ 까지 고른 체장의 분포 로 나타났으며 $13 \mathrm{~mm}$ 이상 성숙한 개체는 채집되지 않았다. 3월에는 채집 된 50 개체의 $6 \%$ 가 $13 \mathrm{~mm}$ 이상 성숙한 개체들이었으며 4 월에는 $36 \%, 5$ 월에는 $42 \%$, 6월에는 $58 \%, 7$ 월에는 $44 \%, 8$ 월에는 $26 \%, 9$ 월에는 $44 \%, 10$ 월에는 $12 \%$ 로 조사되었다. 월별 채집된 50 개체 중 $10 \mathrm{~mm} \sim 12.9 \mathrm{~mm}$ 사이의 개체는 2 월에는 $32 \%, 3$ 월에는 $52 \%, 4$ 월에는 $38 \%, 5$ 월에는 $42 \%$, 6월 에는 $24 \%, 7$ 월에는 $42 \%, 8$ 월에는 $30 \%$, 9월에는 $36 \%, 10$ 월에는 $20 \%$ 로 조사되었다. 월별 채집된 50 개체 중 $7 \mathrm{~mm} \sim 9.9 \mathrm{~mm}$ 사이의 개체는 2 월에는 $46 \%$, 3 월에는 $38 \%, 4$ 월에는 $22 \%, 5$ 월에는 $14 \%, 6$ 월에는 $16 \%, 7$ 월에는 $10 \%, 8$ 월에는 $26 \%$, 9월에는 $18 \%, 10$ 월에는 $15 \%$ 로 조사되었다(Fig. 3).

\subsubsection{2. 외날개꼬마하루살이의 체장의 변화}

2월에는 $3 \mathrm{~mm} \sim 6 \mathrm{~mm}$ 사이의 개체들이 주를 이루 었으며 $7 \mathrm{~mm}$ 이상 성숙한 개체들은 2월에 채집된 50 개체의 $2 \%$ 만이 조사되었으며 3 월 이후 그 수가 증 가하여 3 월에는 $20 \%, 4$ 월에는 $70 \%, 5$ 월에는 $32 \%$, 6월에는 $38 \%, 7$ 월에는 $40 \%, 8$ 월에는 $22 \%, 9$ 월에는 $12 \%, 10$ 월에는 $20 \%$ 로 조사되었다. 월별 채집된 50

Table 2. Changes of Species diversity $\left(H^{\prime}\right)$, species richness(RI), dominance index(DI) to the site

\begin{tabular}{|c|c|c|c|c|c|c|c|c|c|c|c|}
\hline & & Feb. & Mar. & Apr. & May & Jun. & Jul. & Aug. & Sep. & Oct. & Total \\
\hline \multirow{3}{*}{ A } & $H^{\prime}$ & 1.789 & 2.072 & 2.436 & 2.707 & 1.955 & 1.870 & 2.109 & 2.958 & 2.675 & 2.851 \\
\hline & RI & 1.985 & 2.621 & 4.083 & 5.505 & 2.914 & 3.115 & 3.135 & 5.744 & 5.780 & 7.204 \\
\hline & DI & 0.529 & 0.612 & 0.455 & 0.402 & 0.508 & 0.618 & 0.552 & 0.290 & 0.397 & 0.363 \\
\hline \multirow{3}{*}{ B } & $H^{\prime}$ & 2.062 & 2.264 & 2.363 & 2.638 & 2.385 & 2.409 & 2.526 & 1.837 & 2.114 & 3.174 \\
\hline & RI & 2.854 & 2.771 & 3.739 & 4.344 & 3.990 & 3.628 & 4.011 & 2.101 & 3.376 & 8.709 \\
\hline & DI & 0.478 & 0.460 & 0.403 & 0.326 & 0.401 & 0.389 & 0.315 & 0.536 & 0.552 & 0.248 \\
\hline \multirow{3}{*}{$\mathrm{C}$} & $H^{\prime}$ & 2.214 & 2.151 & 1.710 & 1.472 & 1.913 & 2.011 & 2.068 & 2.651 & 1.743 & 2.583 \\
\hline & RI & 3.231 & 3.231 & 3.708 & 2.491 & 2.242 & 3.211 & 2.841 & 5.059 & 2.758 & 7.241 \\
\hline & DI & 0.439 & 0.415 & 0.718 & 0.757 & 0.519 & 0.595 & 0.458 & 0.393 & 0.704 & 0.447 \\
\hline \multirow{3}{*}{ D } & $H^{\prime}$ & 1.507 & 3.115 & 2.459 & 2.735 & 2.665 & 1.760 & 1.987 & 2.437 & 2.555 & 3.222 \\
\hline & RI & 2.058 & 8.843 & 4.295 & 5.157 & 4.864 & 2.140 & 3.104 & 4.085 & 4.534 & 10.216 \\
\hline & DI & 0.667 & 0.322 & 0.434 & 0.325 & 0.320 & 0.595 & 0.582 & 0.451 & 0.372 & 0.325 \\
\hline
\end{tabular}

(A) Woopo site (B) Mokpo site (C) Sajipo site (D)Topyung site 


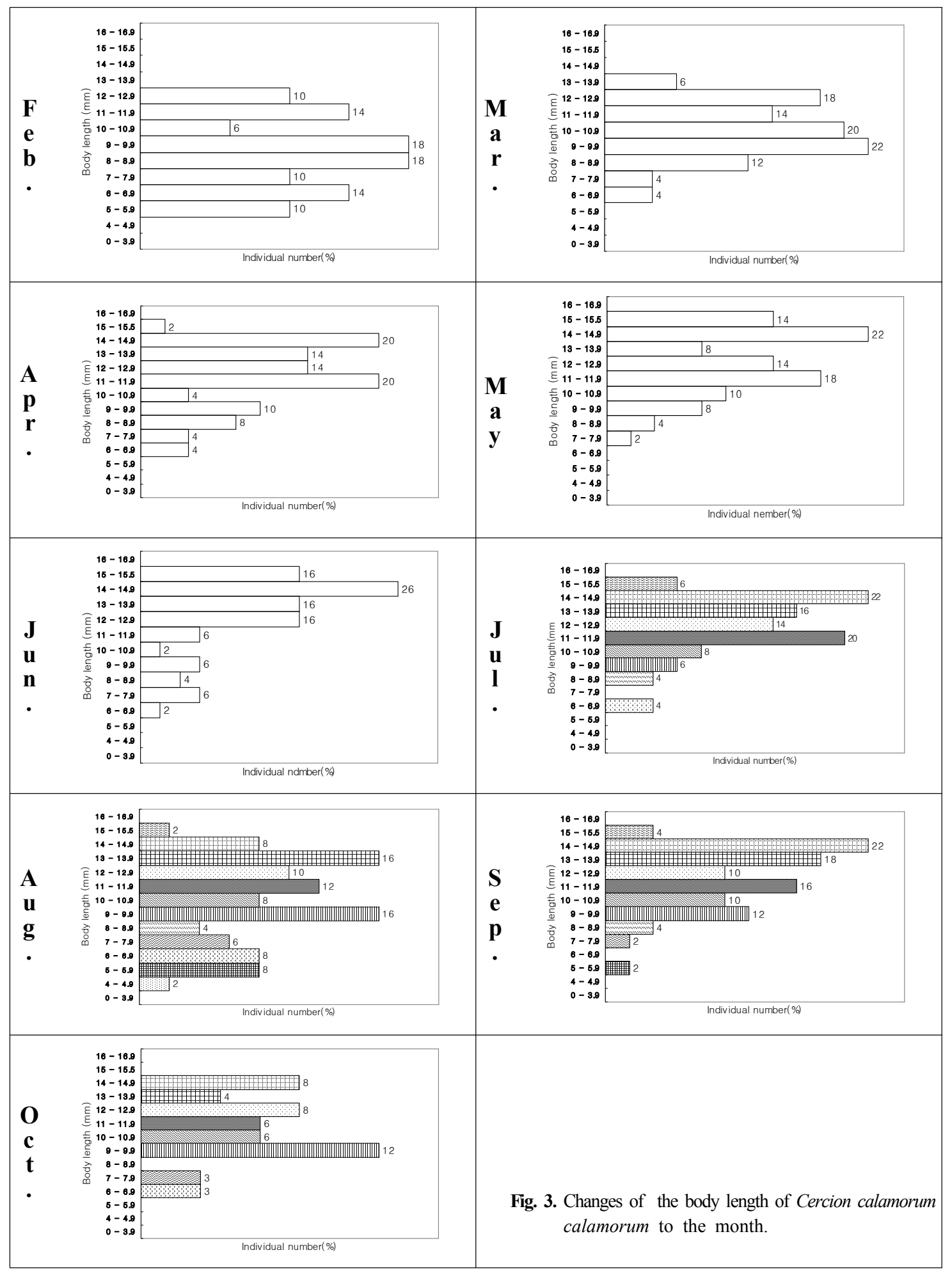




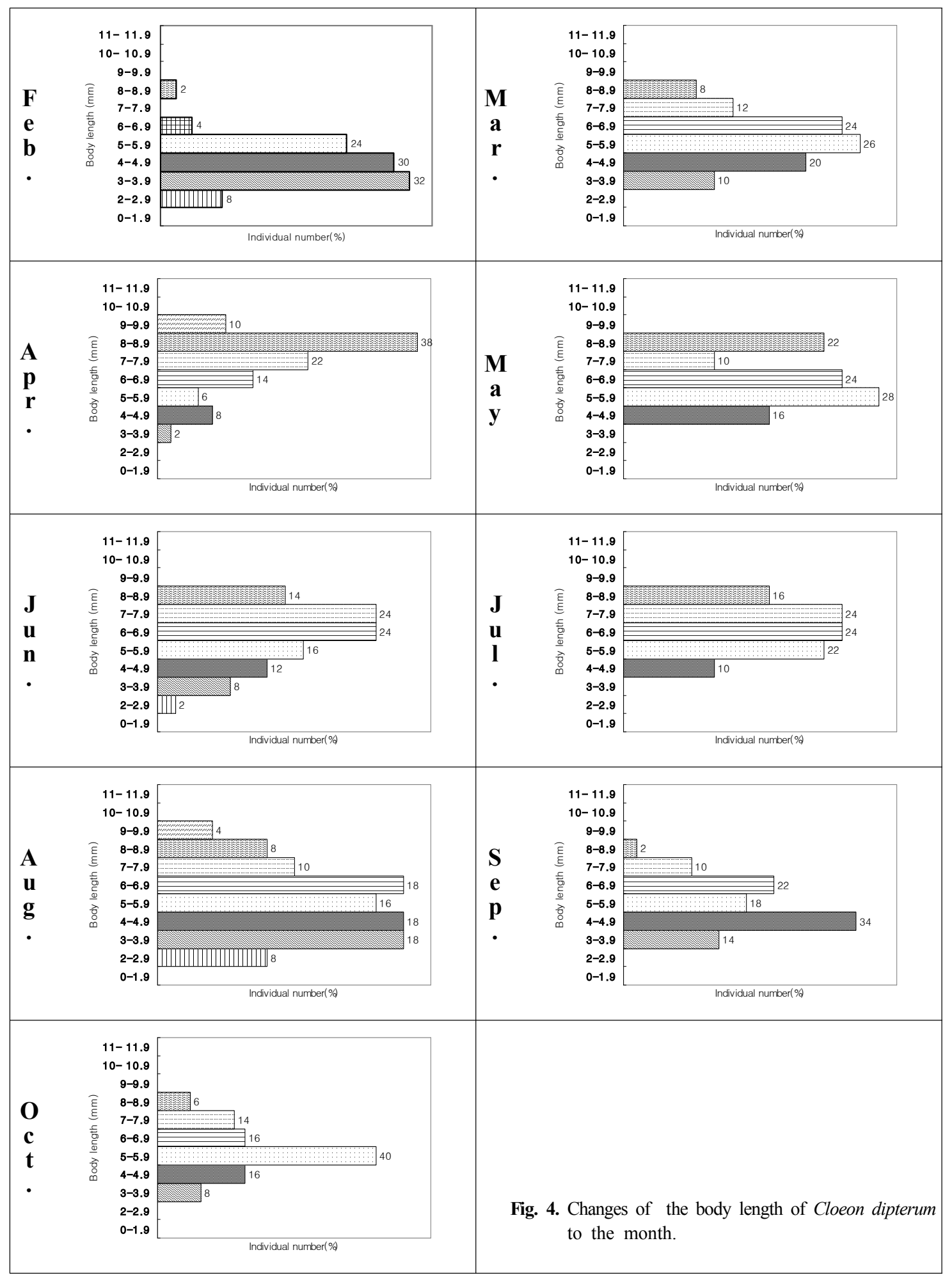


개체 중 $5 \mathrm{~mm} \sim 6.9 \mathrm{~mm}$ 사이의 개체는 2 월에는 $28 \%$, 3 월에는 $50 \%, 4$ 월에는 $20 \%, 5$ 월에는 $52 \%, 6$ 월에는 $40 \%, 7$ 월에는 $46 \%, 8$ 월에는 $34 \%, 9$ 월에는 $40 \%, 10$ 월에는 $56 \%$ 로 조사되었다. 월별 채집된 50 개체 중 $3 \mathrm{~mm} \sim 4.9 \mathrm{~mm}$ 사이의 개체는 2 월에는 $62 \%$, 3 월에 는 $30 \%, 4$ 월에는 $10 \%, 5$ 월에는 $16 \%, 6$ 월에는 $20 \%$, 7 월에는 $10 \%, 8$ 월에는 $36 \%, 9$ 월에는 $48 \%, 10$ 월에는 $24 \%$ 로 조사되었다(Fig. 4).

두 종에 대한 체장변화의 측정 결과는 현재의 시 점에서는 결론을 내리기는 어렵지만 동일방법에 의 해 장기적으로 관측하였을 경우 환경변화가 무척추 동물의 생태에 미치는 영향을 보다 종합적으로 분 석하고 예측하는 것을 가능하게 하는 기초자료가 될 것이다. 특히 기상청의 자료에 따르면 영남지역 은 지난 50 년 간 지구온난화의 영향으로 평균기온 이 $1.2^{\circ} \mathrm{C}$ 나 상승하였으며 현재도 조금씩 상승하고 있는 것으로 나타났는데 온도의 변화에 민감한 이 들의 생태적 특징을 감안하면 이들의 성장이 조금 씩 빨라질 것을 예상할 수 있으며 장기적인 모니터 링을 지속할수록 보다 정확하고 종합적인 자료를 확보할 수 있을 것으로 생각된다.

우포늪 일대에 서식하고 있는 총 6 강 18 목 48 과 95종의 저서성 대형무척추동물이 본 연구기간동안 밝혀졌다. 이러한 조사결과는 국내에서 알려진 정 양지의 56종, 박실지 36종 ${ }^{29)}$, 장척호 29종, 연초호 18 종, 구천호 18 종 ${ }^{30)}$, 주남저수지 55 종 $^{31)}$ 등 타 정수 역의 저서성 대형무척추동물에 비하여 매우 높은 종풍부도를 보여주는 것인데 이는 우포습지가 오랜 기간 보전되어 왔다는 이유 외에도 비교적 넓은 면 적에 비하여 수심이 얕고, 주변의 유입수로부터 영 양물질이 풍부하게 공급되어 전 지역에 걸쳐 수생 식물이 번성하고 있으므로 저서성 대형무척추동물 의 서식처로 이상적이며 수위의 변동이 심하여 유 수지역과 정수지역이 공존하는 다양한 서식환경을 제공하고 있기 때문으로 사료된다.

6월과 7월의 강우로 인한 수환경의 변화는 서식 종 수와 개체수의 감소를 초래하여 군집구조에 영 향을 주는 가장 큰 요인으로 판단된다. 우포늪을 제 외한 지점에서는 출현 종수와 개체수가 6월과 7월에 큰 폭으로 감소하였으며 이후 그 수가 회복 되었다. 우포늪에서는 다른 지역과는 달리 6월에 비해 7월
에 출현 종수와 개체수가 증가하였는데 이때는 각시 물자라(Diplonychus esakii)와 알물 땡땡이(Amphiops mater)가 채집된 개체의 대부분을 차지하였다. 이는 노린재류와 물방개류가 이동성이 강하고 도피능력 이 높아 수량과 유속 등의 물리적인 수환경의 변화 에 대한 적응력이 강하기 때문으로 토평천과 목포 늪에 서식하던 개체의 일부가 증가한 수량과 빨라 진 유속에 떠밀려 우포지역으로 내려와 그대로 정 착한 것이기 때문으로 생각된다.

이번 조사에서는 지금까지 우포늪의 문헌조사에 서 기록되지 않은 종이 29종이 추가로 확인되었다 ${ }^{32)}$. 그러나 아직 국내에서는 많은 분류군의 수서곤충류 가 유충과 성충간의 관계가 연구되지 않아 종 수준 까지 동정하기 어려운 종들이 많다. 본 연구에서도 종 수준까지 동정하기 어려운 종들을 $\mathrm{sp}$.로 기록하 였는데, 정확한 출현종의 파악과 그 종들이 생태계 에 미치는 영향 등을 보다 명확하게 분석하기 위해 서는 현재 연구되지 않은 종들의 생활사를 연구하 는 것이 시급하다 할 수 있다.

매 지점별 우점종은 대부분이 완전 수서생활을 하는 연체동물과 각시물자라 등 환경의 변화에 적 응력이 높은 것으로 생각되는 무척추동물들이 대부 분이었으며 간혹 꼬마둥글물벌레(Plea (Paraplea) indistinguenda)가 대량으로 발생하여 해당 월에 우 점종으로 조사되었다. 토평천은 유속이 빠르지 않 은 유수지역으로 잠자리류의 서식에 적합한 조건을 갖추고 있어 실잠자리류가 우점종으로 조사되기도 하였는데, 하천과 늪지의 전이대로서 많은 잠자리 류 외에도 매우 다양한 종들이 서식하고 있었으며 종다양도와 풍부도도 가장 높게 나타났다.

중점 모니터링대상종으로 선정된 2종에 대한 체 장변화의 모니터링은 현재의 시점에서는 결론을 내 리기는 어렵지만 온도의 변화에 민감한 이들의 생 태적 특징을 감안하면 이들의 성장은 조금씩 빨라 질 것으로 예상되며 장기적인 모니터링을 지속할수 록 보다 정확하고 종합적인 자료를 확보할 수 있을 것으로 생각된다.

\section{4. 결 론}

본 연구는 우포늪일대에서 장기적 모니터링 연구 
를 위하여 그 기반을 조성하고자 저서성 대형무척 추동물의 군집구조를 조사하였다. 우포늪은 경상남 도 창녕군에 위치하고 있으며 국내의 담수습지 중 최대 규모이다. 본 연구에서는 2006년에 4개의 조사 지점에서 매 월 1 회씩 정량조사와 정성조사를 병행 하여 실시하였다. 본 조사기간 동안 밝혀진 저서성 대형무척추동물은 총 6강 18목 48과 95종으로 매우 다양한 종류의 저서성 대형무척추동물이 우포늪일 대에 서식하고 있음이 밝혀졌다. 종다양도와 풍부 도는 토평천지역에서 3월에 각각 3.115와 2.058로 가장 높게 나타났다. 외날개꼬마하루살이와 등검은 실잠자리 두 종을 9 개월간 정량 채집하여 50 개체에 대한 체장변화를 조사하였다. 그 결과 두 종에 대한 성장이 점차 앞당겨질 것을 예상할 수 있었다.

\section{감사의 글}

본 연구는 환경부의 “국가장기생태연구과제” 지 원으로 수행되었습니다.

\section{참 고 문 헌}

1) Spellerberg I. F., 1991, Monitoring ecological change. Cambridge University Press, 334pp.

2) Degaetano A. T., 2005, Meteorological effects on adult mosquito (Culex) populations in metropolitan New Jersey, Int J Biometeorol, 49(5), 345-353.

3) Pennak R. W., 1989, Fresh-water invertebrates of the United States(3rd ed.), John Wiley \& Sons, New York. 628pp.

4) 윤일병, 1995 , 수서곤충검색도설, 정행사, $262 \mathrm{pp}$.

5) Ward J. V., 1992, Aquatic insect ecology, John Wiley \& Sons., 438pp.

6) 환경청, 1987 , 우포늪. 주남저수지 생태계조사, 저 서동물상, 107-127.

7) 창녕군, 1997 , 우포·목포늪 생태계 보전방향, 85 112.

8) 배연재, 조신일, 황득휘, 이황구, 나국본, 2004, 우 포습지의 저서성 대형무척추동물 다양성과 군집특 성, 한국환경생태학회지, 18(1), 75-91.

9) 환경부, 2001 , 전국자연환경조사지침, $150 \mathrm{pp}$.

10) McCafferty W. P., 1981, Aquatic entomology, John \& Bartlett, Boston. 448pp.

11) Williams D. D. and B. W. Feltmate, 1992, Aquatic insects, CBA International, Oxon, UK. 358pp.

12) Allan J. D., 1995, Stream ecology. Structure and function of running waters, Chapman \& Hall,Landon, 388pp.

13) Merritt R. W. and K. W. Cummins, 1996, An introduction to the aquatic insects of North America, 3rd ed, Kendall/Hunt, Dubuque, Iowa. 862pp.

14) 강동완, 1988 , 전남산 턱거머리목의 분류학적 연구, 고려대학교 교육학석사논문, $39 \mathrm{pp}$.

15) 권오길, 1990 , 한국동식물도감 제 32권 동물편(연체 동물 I), 문교부, 446pp.

16) 김훈수, 1977 , 한국동식물도감 제 19 권 동물편(새우 류), 문교부, $445 \mathrm{pp}$.

17) 윤일병, 1988 , 한국동·식물 도감 제 30 권(수서곤충 류), 문교부, 840pp.

18) 윤일병, 안기정, 1986 , 한국산 물방개과의 분류학적 연구 I (알물방개아과), The Korean J. of Entomology, $16(2), 145-151$

19) 윤일병, 안기정, 1988 , 한국산 물방개과의 분류학적 연구III '등줄물방개아과, 물방개붙이아과', The Korean J.of Entomology, 18(4), 251-268.

20) 이상협, 1992, 한국산 넓적거머리과(거머리강 : 문 질목)의 분류 및 생태학적 연구, 고려대 석사논문, $43 \mathrm{pp}$.

21) 이창언, 조복성, 이관우, 김창환, 이택중, 박성호, 1971 , 한국동식물도감 제 12 권 동물편(IV), 문교부, 386-448.

22) 조복성, 1969 , 한국동식물도감 동물편(곤충류 II), 문교부, 165-190.

23) 川合㜥次(編), 1985, 日本産水生昆蟲檢索圖說, 東海 大學出版會, $409 \mathrm{pp}$.

24) 丸山傳紀, 高井幹夫, 2003, 原色 川虫圖鑑, 全國農 村教育協會, $244 p p$.

25) 한국곤충학회, 한국응용곤충학회, 1994 , 한국곤충 명집, 건국대학교출판부, $744 \mathrm{pp}$.

26) 한국동물분류학회, 1997 , 한국동물명집(곤충제외), 아카데미서적, $489 \mathrm{pp}$.

27) Shannon C. E. and W. Weaner, 1949, The mathematical theory of communication Univ, Illinois press, Urban, IL.

28) Margalef R., 1957, La teoria de la informacion en ecologia, Mem. Real Acad. Cienc. Artes Barcelona, 32, 373-449.

29) 정선우, 윤춘식, 김인택, 박정원, 윤춘식, 2005. 합천 군 정양지와 박실지의 곤충 및 저서성 대형무척추 동물의 분포, 환경연구논문집, 5(1), 94-100.

30) 정선우, 박정원, 전세근, 윤춘식, 2004, 거제도 구천 호와 연초호의 곤충과 저서성 대형무척추동물의 분포, 환경연구논문집, 4(1), 83-90.

31 ) 정선우, 윤춘식, 전세근, 김산, 2003, 주남저수지의 어류 및 대형저서성동물의 군집구조, 창원대학교 기초과학연구소, 23-30.

32) 여상덕, 윤일병, 1997, 우포.목포늪 생태계보전방향 '우포.목포늪 수서곤충류 조사연구, 경남개발연구 원', 51-61. 